\title{
Spatially resolved information on karst conduit flow from in-cave dye tracing
}

\author{
U. Lauber ${ }^{1}$, W. Ufrecht ${ }^{2}$, and N. Goldscheider ${ }^{1}$ \\ ${ }^{1}$ Institute of Applied Geosciences, Division of Hydrogeology, Karlsruhe Institute of Technology (KIT), Kaiserstr. 12, \\ 76131 Karlsruhe, Germany \\ ${ }^{2}$ Höhlen- und Heimatverein Laichingen, Höhleweg 220, 89159 Laichingen, Germany
}

Correspondence to: U. Lauber (ute.lauber@kit.edu) and N. Goldscheider (goldscheider@kit.edu)

Received: 5 August 2013 - Published in Hydrol. Earth Syst. Sci. Discuss.: 5 September 2013

Revised: 12 December 2013 - Accepted: 12 December 2013 - Published: 5 February 2014

\begin{abstract}
Artificial tracers are powerful tools for investigating karst systems. Tracers are commonly injected into sinking streams or dolines, while springs serve as monitoring sites. The obtained flow and transport parameters represent mixed information from the vadose, epiphreatic and phreatic zones (that is, the aquifer remains a black box). Accessible active caves constitute valuable but underexploited natural laboratories to gain detailed insights into the hydrologic functioning of the aquifer. Two multi-tracer tests in the catchment of a major karst spring (Blautopf, Germany) with injections and monitoring in two associated water caves aimed at obtaining spatially and temporally resolved information on groundwater flow in different compartments of the system. Two tracers were injected into the caves to characterize the hydraulic connections between them and with the spring. Two injections at the land surface, far from the spring, aimed at resolving the aquifer's internal drainage structure. Tracer breakthrough curves were monitored by field fluorimeters in caves and at the spring. Results demonstrate the dendritic drainage structure of the aquifer. It was possible to obtain relevant flow and transport parameters for different sections of this system. The highest mean flow velocities $\left(275 \mathrm{~m} \mathrm{~h}^{-1}\right)$ were observed in the near-spring epiphreatic section (openchannel flow), while velocities in the phreatic zone (pressurized flow) were one order of magnitude lower. Determined conduit water volumes confirm results of water balances and hydrograph analyses. In conclusion, experiments and monitoring in caves can deliver spatially resolved information on karst aquifer heterogeneity and dynamics that cannot be obtained by traditional investigative methods.
\end{abstract}

\section{Introduction}

Karst aquifers are characterized by strong heterogeneity and anisotropy related to the diverse distribution of solutionally enlarged conduits in the carbonate rock (Worthington and Ford, 2009). Groundwater flow and contaminant transport in karst aquifers are difficult to predict because of the unknown configuration and geometry of the conduit network. However, the sustainable use and protection of karst groundwater resources requires detailed knowledge of the underground flow paths and spring catchment areas. Geological mapping and speleological investigations can deliver direct information about karst development and the presence of larger conduits (Goldscheider and Drew, 2007). Further insights into drainage structures and dominating transit times can be achieved by observations of spring hydrographs and environmental tracers (e.g., electrical conductivity, hydrochemical components and isotopes) (Winston and Criss, 2004; Ravbar et al., 2011; Mudarra and Andreo, 2011). Artificial tracer tests are often used to investigate the drainage pattern of karst aquifers. In contrast to other methods, tracer tests deliver clear information on hydraulic connections, spring catchment areas, transit time distributions and linear flow velocities. Relevant conservative and reactive transport parameters, such as dispersion and retardation can be obtained by quantitative analysis and modeling of tracer breakthrough curves (BTCs) (e.g., Geyer et al., 2007; Massei et al., 2006; Morales et al., 2007; Goldscheider et al., 2008). In most cases, tracers are injected into stream sinks, dolines or other surface karst structures, while springs serve as sampling and monitoring sites. Consequently, all obtained data 
and parameters represent mixed information from the entire flow path between the injection and recovery sites (i.e., from the unsaturated (vadose), epiphreatic and phreatic (saturated) zones of the aquifer). However, flow velocities and transport parameters are highly variable between and within these zones.

Experiments and monitoring in caves make it possible to obtain more detailed insights into the internal structure and hydraulic functioning of karst aquifer systems (Goldscheider et al., 2008). Owing to the difficult to near-impossible access to active caves, as well as the associated cost and dangers, this approach has not been used very often. In this sense, caves are valuable but underexploited natural laboratories for hydrologic research. Perrin et al. (2007) quantified the role of tributary mixing in chemical variability at a karst spring by means of detailed monitoring inside a cave system. Meiman et al. (2001) conducted in-cave dye-tracer tests to delineate subbasins within the Mammoth Cave aquifer. The hierarchical structure of conduit systems is known from speleological observations (Palmer, 1991) and numerical simulations of speleogenesis (Gabrovsek et al., 2004; Dreybrodt et al., 2010). Tracer tests in caves can help to reveal the drainage structure of inaccessible conduit systems (e.g., Smart, 1988). In-cave tracer tests have also previously been used to determine flow velocities and dispersion in openchannel cave streams at local scales (Hauns et al., 2001) and to compare the transport of solutes and colloids (Göppert and Goldscheider, 2008). Tracer injections at the land surface and monitoring of water inlets in caves can help to quantify water storage, percolation and contaminant transport in the epikarst zone (Pronk et al., 2009).

In order to obtain spatially and temporally resolved information on conduit flow in karst aquifer systems, a karst catchment in southern Germany that includes two major caves and is drained by a large spring was selected as a test site for this study. This paper presents the first tracer tests that were done inside the active conduit network of this karst system, accompanied by detailed geological investigations and water balances (Lauber et al., 2013). The experimental approach consists of two in-cave dye-tracer injections and two injections at the land surface, with detailed monitoring at several sampling sites inside the caves and at the spring (Figs. 1 and 2).

There were five major goals to this study: (1) localize and quantify the hydraulic connections between the two water caves and towards the karst spring; (2) reveal and characterize the supposed hierarchical drainage structure of the aquifer system; (3) delineate subcatchments within the large overall spring catchment area; (4) obtain spatially resolved information on flow velocities and transport parameters in the vadose, epiphreatic and phreatic zones; and (5) estimate the water volume in the conduit network in comparison with results of other studies.

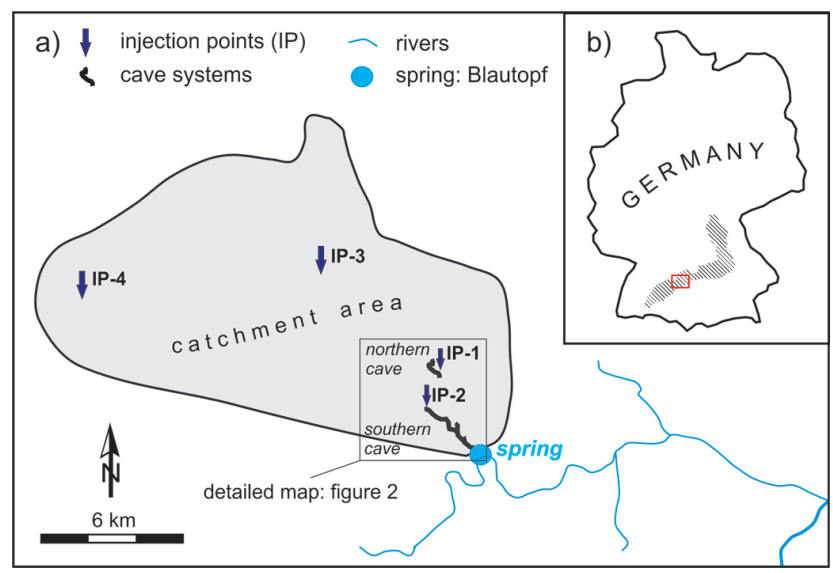

Fig. 1. (a) Catchment area of the Blautopf spring with location of the Blue Cave system (southern cave), the Hessenhau Cave (northern cave) and the four tracer injection sites (IP-1 to IP-4). (b) Location of the test site (rectangle) within the southern German karst region of the Swabian and Franconian Alb (shaded).

\section{Field site}

The Blautopf ("Blue Pot") spring is located at the southern margin of the Swabian-Franconian Alb, Germany's largest karst area (Fig. 1). It drains an area of $165 \mathrm{~km}^{2}$ and has a mean discharge of $2.3 \mathrm{~m}^{3} \mathrm{~s}^{-1}$, with variation ranging from $0.3 \mathrm{~m}^{3} \mathrm{~s}^{-1}$ in dry periods up to $32.5 \mathrm{~m}^{3} \mathrm{~s}^{-1}$ during high-flow conditions. The stratigraphy is composed of a series of Upper Jurassic limestone and marl with a total thickness of up to $400 \mathrm{~m}$. The aquifer system consists of an upper and lower karst aquifer, separated and underlain by marl aquitards (Bartenbach et al., 2009; Lauber et al., 2013). The landscape is characterized by numerous dolines and dry valleys. The lowering of the main valley during the Plio-Pleistocene and the subsequent backfilling with gravel have created a deep karst system; that is, the basis of the karst aquifer is below the level of the valley and main spring (Bartenbach and Ufrecht, 2009; Ufrecht, 2009). Blautopf spring cannot safely be used for drinking-water supply because wastewater and agricultural runoff have adversely affected the water quality of the spring.

Since 1975, more than 65 tracer tests have been conducted in the catchment area. All injections were done at the land surface, mostly into dolines or stream sinks (Villinger and Ufrecht, 1989; Selg and Schwarz, 2009). Therefore, the catchment area of the spring is well known (Armbuster and Selg, 2006). However, the internal drainage structure of this aquifer system had previously been unknown due to great difficulties in accessing existing caves.

To date, more than 150 caves have been mapped in the area (Arbeitsgemeinschaft Blautopf, 2011; Bohnert, 2009). The most important one is the Blauhöhlensystem ("Blue Cave system", southern cave in Figs. 1 and 2). Previously, the Blautopf spring was the only entrance to the systems. 
Cavers had to dive $1200 \mathrm{~m}$ in order to access and explore the inner parts of this cave. The Blue Cave system is more than $10 \mathrm{~km}$ long and consists of phreatic (fully watersaturated), epiphreatic (open-channel flow) and vadose passages (Fig. 2). Another important cave is the $3.5 \mathrm{~km}$ long Hessenhauhöhle ("Hessenhau Cave", northern cave). The entrance of the cave is a vertical shaft under a doline passing into a horizontal water cave at a depth of $130 \mathrm{~m}$ (Fig. 2). This cave was presumed to drain towards the Blue Cave system and Blautopf spring; however, there is no clear evidence for this. Since 2010, a drilled shaft has permitted access to the Blue Cave system without diving, providing an easier way for scientific research to be carried out within the cave systems.

\section{Methods}

\subsection{Tracer tests}

The first two tracer injections into cave streams were done on 21 April 2012: $100 \mathrm{~g}$ of uranine was injected into the northern cave at IP-1, and $200 \mathrm{~g}$ of sulforhodamine $\mathrm{G}$ (sulfoG) was injected into the southern cave at IP-2 (Figs. 1 and 2). One week later, on 28 April 2012, two injections were done at the land surface, in distal parts of the catchment area. Due to the first two tracers being injected directly into the cave streams, it was possible to use the same two dye tracers again. In the conduit systems, no significant storage possibilities were to be expected under stable flow conditions. Monitoring in the active caves and at the spring demonstrated that tracer concentrations from the first experiment had dropped below the detection limit. Based on this, $1500 \mathrm{~g}$ of uranine was injected into a vertical karst shaft at IP-3, about $10 \mathrm{~km}$ away from the spring. For decades, this shaft had been used to dispose of overflow water from a sewage treatment plant. At IP-4, $19 \mathrm{~km}$ away from the spring (Fig. 1), $2000 \mathrm{~g}$ of sulfoG was injected into a doline. A minimum of $78 \mathrm{~m}^{3}$ of water was used at each surface injection site to flush the tracer through the vadose zone.

In order to obtain detailed tracer breakthrough curves, a total of three field fluorimeters (GGUN-FL 43, 334 and 335; Albillia, Switzerland) were installed at sampling points in the cave system (SP-2 and 3) and at the spring (SP-4) (Fig. 2). The fluorimeters were calibrated using water from the cave system; the sampling interval during the tracer tests was $4 \mathrm{~min}$. At SP-1, water samples were collected by cavers; water samples were also collected at other sites in order to check the fluorimeter results. Additionally, charcoal bags were placed at several sites in the cave system and replaced at intervals of two weeks or less. Qualitative results from the charcoal bags were obtained to better resolve the spatial flow pattern, in particular the location of the confluence between the two caves. Water samples and charcoal bags were analyzed in the KIT laboratory using a spectrofluorimeter (LS 55, Perkin Elmer).
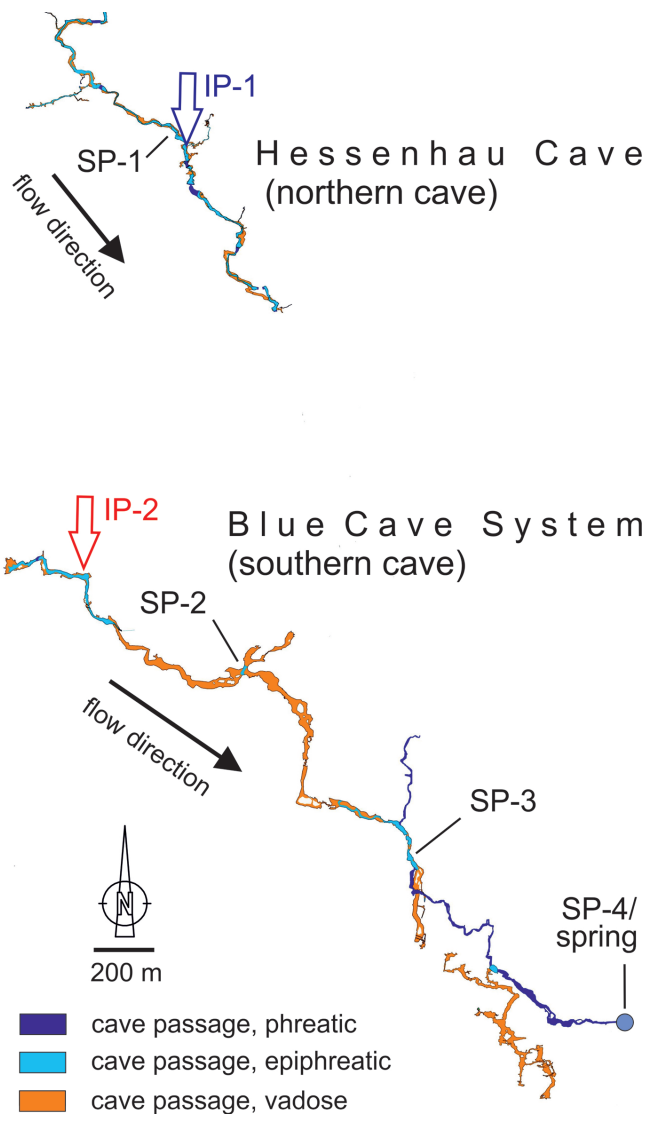

Fig. 2. Map of the two caves with indication of phreatic, epiphreatic and vadose cave passages, injection points IP- 1 and IP-2 in the cave streams, and sampling points (SP-1 to SP-4).

Discharge measurements were conducted in the two cave systems at SP-1 and SP-2 one week before the tracer tests using the salt-dilution method. The data make it possible to relate cave stream flow and spring discharge. Continuous discharge data from the spring were obtained from the regional authority for water balance calculations and for estimation of the total recovery and water volumes in the cave system.

\subsection{Evaluation and modeling of the results}

Flow velocities and dispersion/dispersivity were calculated with and without considering tortuosity $\left(\tau=x_{\tau} / x\right)$. While the surveyed length $\left(x_{\tau}\right)$ of the phreatic cave passage between SP-3 and the spring is $1200 \mathrm{~m}$, the linear distance $(x)$ is only $700 \mathrm{~m}$ (Fig. 2). Thus, a tortuosity of 1.7 can be defined for this karst system. For the sake of simplicity, all velocities and dispersions mentioned in the text do not consider tortuosity. The complete results (with and without tortuosity) are provided in Table 1.

All breakthrough curves (BTCs) were analytically modeled with a conventional advection-dispersion model (ADM) and a two-region non-equilibrium (2RNE) model using the software CXTFIT (Toride et al., 1999). The models calculate 
Table 1. Results of the tracer test.

\begin{tabular}{|c|c|c|c|c|c|c|}
\hline & Injection Points & & IP-1 & IP-2 & IP-3 & IP-4 \\
\hline Injection & Tracer & & Uranine & SulfoG & Uranine & SulfoG \\
\hline Sampling & Type of injection point & & Cave stream & Cave stream & Karst shaft & Doline \\
\hline Sampling Points & Parameter & Unit & & & & \\
\hline SP-1 & $\begin{array}{l}\text { Time of first detection } \\
\text { Maximum velocity }^{\mathrm{a}}\end{array}$ & $\begin{array}{l}\mathrm{h} \\
\mathrm{mh}^{-1}\end{array}$ & $=$ injection point & no detection & $\begin{array}{l}98.1 \\
69 / 118\end{array}$ & no detection \\
\hline SP-2 & $\begin{array}{l}\text { Time of first detection } \\
\text { Peak time } \\
\text { Maximum concentration } \\
\text { Maximum velocity } \\
\text { Peak velocity } \\
\text { Mean flow velocity } \\
\text { Dispersion } \\
\text { Dispersivity }\end{array}$ & $\begin{array}{l}\mathrm{h} \\
\mathrm{h} \\
\mu \mathrm{g} \mathrm{L}-1 \\
\mathrm{~m} \mathrm{~h}^{-1} \\
\mathrm{~m} \mathrm{~h}^{-1} \\
\mathrm{mh}^{-1} \\
\mathrm{~m}^{2} \mathrm{~h}^{-1} \\
\mathrm{~m}\end{array}$ & no detection & $\begin{array}{l}1.2 \\
2.3 \\
50 \\
578 / 983 \\
290 / 493 \\
275 / 468 \\
4920 / 14200 \\
18 / 30\end{array}$ & no detection & $\begin{array}{l}320 \\
360 \\
0.6 \\
51 / 87 \\
45 / 77 \\
- \\
- \\
-\end{array}$ \\
\hline SP-3 & $\begin{array}{l}\text { Time of first detection } \\
\text { Peak time } \\
\text { Maximum concentration } \\
\text { Maximum velocity } \\
\text { Peak velocity } \\
\text { Mean flow velocity } \\
\text { Dispersion } \\
\text { Dispersivity }\end{array}$ & $\begin{array}{l}\mathrm{h} \\
\mathrm{h} \\
\mu \mathrm{g} \mathrm{L}-1 \\
\mathrm{mh}^{-1} \\
\mathrm{~m} \mathrm{~h}^{-1} \\
\mathrm{~m} \mathrm{~h}^{-1} \\
\mathrm{~m}^{2} \mathrm{~h}^{-1} \\
\mathrm{~m}\end{array}$ & $\begin{array}{l}26.0 \\
31.8 \\
1.9 \\
96 / 163 \\
78 / 132 \\
74 / 130 \\
734 / 2350 \\
10 / 18\end{array}$ & $\begin{array}{l}12.0 \\
15.9 \\
6.0 \\
152 / 258 \\
115 / 195 \\
112 / 191 \\
1160 / 3360 \\
10 / 17\end{array}$ & $\begin{array}{l}136 \\
155 \\
11.5 \\
68 / 115 \\
60 / 102 \\
56 / 100 \\
794 / 2290 \\
14 / 23\end{array}$ & $\begin{array}{l}335 \\
385 \\
0.5 \\
54 / 91 \\
46 / 79 \\
45 / 74^{\mathrm{b}} \\
6230 / 16700^{\mathrm{b}} \\
138 / 225^{\mathrm{b}}\end{array}$ \\
\hline SP-4 & $\begin{array}{l}\text { Time of first detection } \\
\text { Peak time } \\
\text { Maximum concentration } \\
\text { Distance to spring } \\
\text { Maximum velocity } \\
\text { Peak velocity } \\
\text { Spring discharge } \\
\text { Recovery } \\
\text { Mean flow velocity } \\
\text { Dispersion } \\
\text { Dispersivity } \\
\text { Partitioning coefficient } \beta \\
\text { Mass transfer coefficient } \omega\end{array}$ & $\begin{array}{l}\mathrm{h} \\
\mathrm{h} \\
\mu \mathrm{g} \mathrm{L} \\
\mathrm{km} \\
\mathrm{mh}^{-1} \\
\mathrm{mh}^{-1} \\
\mathrm{~m}^{3} \mathrm{~s}^{-1} \\
\% \\
\mathrm{mh}^{-1} \\
\mathrm{~m}^{2} \mathrm{~h}^{-1} \\
\mathrm{~m} \\
- \\
-\end{array}$ & $\begin{array}{l}41.0 \\
48.8 \\
1.1 \\
3.2 / 5.4 \\
78 / 132 \\
65 / 111 \\
1.24 \\
52 \\
64 / 110 \\
784 / 2270 \\
12 / 20 \\
0.96 \\
0.57\end{array}$ & $\begin{array}{l}25.6 \\
29.2 \\
4.0 \\
2.5 / 4.3 \\
98 / 167 \\
86 / 147 \\
1.32 \\
79 \\
74 / 133 \\
1120 / 3300 \\
15 / 25 \\
0.89 \\
0.82\end{array}$ & $\begin{array}{l}153 \\
177 \\
10.3 \\
10 / 17 \\
65 / 111 \\
56 / 96 \\
1.04 \\
63 \\
56 / 95 \\
727 / 2100 \\
12 / 22 \\
0.97 \\
0.39\end{array}$ & $\begin{array}{l}357 \\
405 \\
0.14 \\
19 / 32 \\
53 / 91 \\
46 / 80 \\
0.97 \\
5 \\
45 / 76^{\mathrm{b}} \\
3260 / 9240^{\mathrm{b}} \\
74 / 121^{\mathrm{b}} \\
0.91^{\mathrm{b}} \\
1.37^{\mathrm{b}}\end{array}$ \\
\hline
\end{tabular}

Note: mean flow velocity and dispersion are calculated by using the ADM of the software CXTFIT (Toride et al., 1999). Coefficients of determination are all greater than 0.931 except for IP-4 $\left(R^{2}>0.8\right)$. Values are determined without/with respect to tortuosity. Partitioning coefficients and mass transfer coefficients are calculated by using $2 \mathrm{RNE}$ model of CXTFIT. ${ }^{\mathrm{a}}$ incomplete BTC; ${ }^{\mathrm{b}}$ parameters are only calculated for the first peak.

one-dimensional flow in karst conduits, which is predominantly characterized by advection, i.e., flow velocity $(v)$, and mechanical dispersion $(D)$ in the direction of flow. The general advection-dispersion equation (Eq. 1) is solved analytically by assuming homogeneous profiles, a uniform and unidirectional flow field that is constant in time and space, and constant flow parameters (van Genuchten et al., 2012). An inverse modeling tool of the ADM provides best estimates of the two flow parameters $(v, D)$ by fitting a modeled BTC to observed values.

$\frac{\partial c}{\partial t}=D \frac{\partial^{2} c}{\partial x^{2}}-v \frac{\partial c}{\partial x}$
The 2RNE model further accounts for exchange between mobile and immobile fluid regions in the karst system (Field and Pinsky, 2000). Therefore, the advection-dispersion equation is extended by two parameters, a partitioning coefficient $\beta$ between mobile and immobile fluid regions and a mass transfer coefficient $\omega$ between the two regions. Thus, a total of four parameters $(v, D, \beta, \omega)$ need to be fitted simultaneously, resulting in less robust (i.e., more ambiguous) estimates (van Genuchten et al., 2012). Due to the nearly symmetric shapes of the breakthrough curves and the short tailing, most of the BTCs were fitted well by both models. Therefore, the ADM was used to obtain more robust values; the results are listed in Table 1 and used for discussion. 


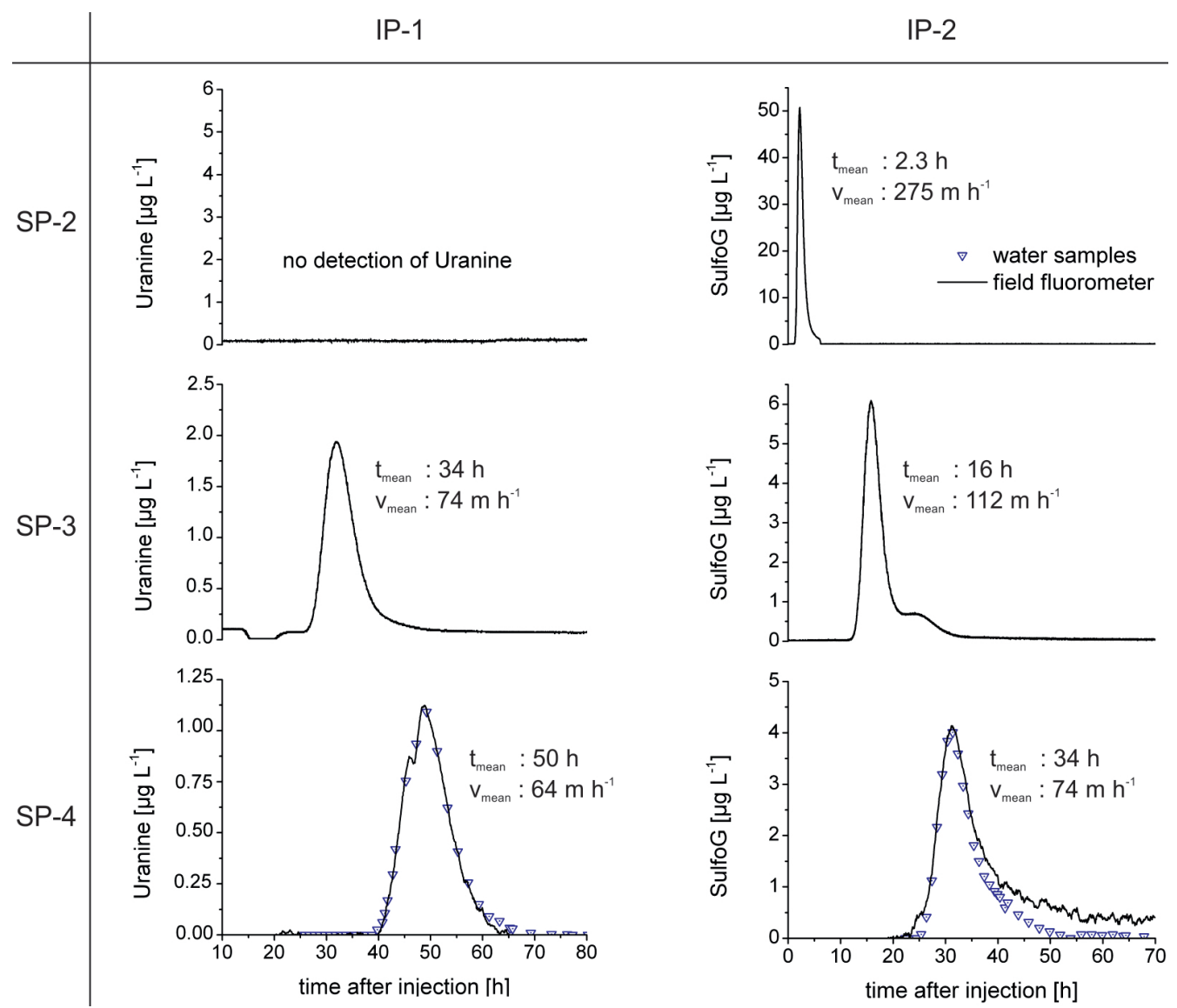

Fig. 3. Breakthrough curves resulting from in-cave dye-tracer injection at IP-1 (uranine) and IP-2 (sulfoG) obtained at sampling points in the cave (SP-2, SP-3) and at the spring (SP-4).

Based on the modeling, mean flow velocities and dispersion coefficients were determined between the four injection sites and the four sampling sites. In order to quantify flow velocities between individual sampling points (e.g., the section between SP-2 and SP-3 or between SP-3 and SP4), peak transit times were used. Effects of the vadose zone were estimated by comparing parameters from surface and cave injections. Additional flow parameters for epiphreatic and phreatic zones (i.e., the partitioning coefficient and the mass transfer coefficient) were determined with the 2RNE model for selected BTCs of cave injections. Water volumes $(V)$ of the karst conduit system were estimated by multiplying the mean discharge $\left(Q_{\text {mean }}\right)$ and the mean transit time of the tracer $\left(t_{\text {mean }}\right)$ (Field and Nash, 1997).

\section{Results and discussion}

\subsection{Results of the tracer injections in cave streams}

All observed BTCs resulting from the two injections in cave streams (IP-1 and IP-2) show a single and nearly symmetric peak and a short tailing (Fig. 3). Uranine (IP-1) was de- tected at SP-3 and at the spring (SP-4). The first detection occurred $26 \mathrm{~h}$ after injection. The maximum concentration of $1.9 \mu \mathrm{g} \mathrm{L}^{-1}$ was reached after $32 \mathrm{~h}$. At SP-4, uranine was first detected after $41 \mathrm{~h}$, and the maximum of $1.1 \mu \mathrm{g} \mathrm{L}^{-1} \mathrm{oc}-$ curred after $49 \mathrm{~h}$. Spring discharge was about $1.24 \mathrm{~m}^{3} \mathrm{~s}^{-1}$. Despite direct injection into the cave stream, total tracer recovery only reached $52 \%$ (Table 1 ). Mean flow velocities of $74 \mathrm{~m} \mathrm{~h}^{-1}$ and a dispersion of $734 \mathrm{~m}^{2} \mathrm{~h}^{-1}$ were calculated between IP-1 and SP-3 (without considering tortuosity). Between IP-1 and SP-4, mean flow velocities were lower, $64 \mathrm{~m} \mathrm{~h}^{-1}$, with dispersion of $784 \mathrm{~m}^{2} \mathrm{~h}^{-1}$. The flow velocities in the phreatic sections between SP-3 and SP-4 are based on peak transit times and are about $41 \mathrm{~m} \mathrm{~h}^{-1}$. Uranine was not detected in the more distant and upstream part of the southern cave at SP-2.

SulfoG (IP-2) was detected at all three sampling points - SP-2, SP-3 and SP-4 - tracing the flow path through the southern cave. The first arrival at SP-2 occurred $1 \mathrm{~h}$ after injection; the maximum of $50 \mu \mathrm{g} \mathrm{L}^{-1}$ was reached after $2.3 \mathrm{~h}$ (Fig. 3). At SP-3, first detection was after $12 \mathrm{~h}$, and a maximum concentration of $6 \mu \mathrm{g} \mathrm{L}^{-1}$ was measured after $16 \mathrm{~h}$. SulfoG arrived after $26 \mathrm{~h}$ at the spring, where the maximum of 


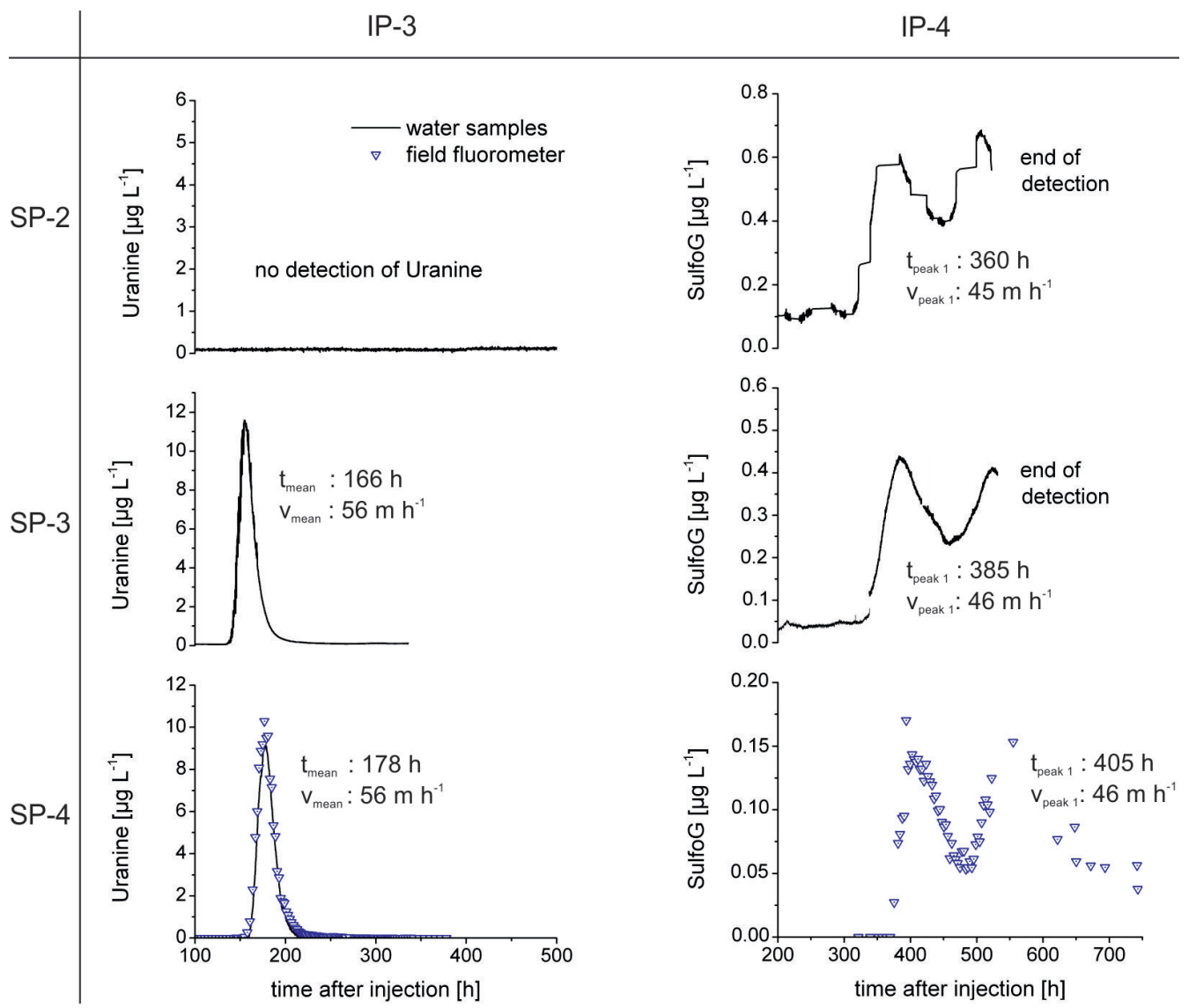

Fig. 4. Breakthrough curves resulting from injections at the land surface, at IP-3 (uranine) and IP-4 (sulfoG), observed at sampling points in the cave (SP-2, SP-3) and at the spring (SP-4).

$4.0 \mu \mathrm{g} \mathrm{L}^{-1}$ occurred after $29 \mathrm{~h}$. During breakthrough, spring discharge was $1.32 \mathrm{~m}^{3} \mathrm{~s}^{-1}$, and $79 \%$ of the tracer was recovered (Table 1). Highest mean flow velocities, $275 \mathrm{~m} \mathrm{~h}^{-1}$, were calculated for the epiphreatic section between IP-2 and SP-2, with dispersion of $4920 \mathrm{~m}^{2} \mathrm{~h}^{-1}$. Significantly lower values for mean flow velocity $\left(112 \mathrm{mh}^{-1}\right)$ and dispersion $\left(1160 \mathrm{mh}^{-1}\right)$ were found between IP-2 and SP-3. Coefficients of determination $\left(R^{2}\right)$ from modeled BTCs in the cave system are greater than 0.931 , showing good curve fitting. The lowest flow velocities, $47 \mathrm{mh}^{-1}$, were measured in the phreatic section between SP-3 and the spring and are based on peak transit times. After $75 \mathrm{~h}$, concentrations at the spring had decreased below detection limits (Fig. 3).

\subsection{Results of the tracer injections at the land surface}

Uranine (IP-3) was detected at SP-1, SP-3 and the spring (SP-4) (Fig. 4). Due to poor accessibility to the northern cave, sampling at SP-1 was only temporarily feasible; as a result the BTC is incomplete. Uranine was first detected at SP-1 after $98 \mathrm{~h}$. The first arrival at SP-3 occurred after $136 \mathrm{~h}$, and the maximum of $11.5 \mu \mathrm{g} \mathrm{L}^{-1}$ was reached after $155 \mathrm{~h}$. At SP-4, first detection was after $153 \mathrm{~h}$ and a maximum concentration of $10.3 \mu \mathrm{g} \mathrm{L}-1$ was measured after $177 \mathrm{~h}$. Despite the injection via the unsaturated zone (into a karst shaft), the BTCs display a single peak and nearly symmetric shapes. During breakthrough, spring discharge was about $1.04 \mathrm{~m}^{3} \mathrm{~s}^{-1}$, and a recovery of $63 \%$ was calculated (Table 1). Maximum flow velocity between IP-3 and SP-1 is $69 \mathrm{~m} \mathrm{~h}^{-1}$. Mean flow velocity from IP-3 to SP-3 was calculated at $56 \mathrm{~m} \mathrm{~h}^{-1}$, dispersion being $794 \mathrm{~m}^{2} \mathrm{~h}^{-1}$. The ADM provides good curve fitting, with $R^{2}$ values greater than 0.973 . Approaching the spring, flow velocities between SP-3 and SP-4 decline to $27 \mathrm{~m} \mathrm{~h}^{-1}$ and are based on peak transit times.

SulfoG from IP-4 was only detected in the southern cave. All BTCs at SP-2, SP-3 and the spring (SP-4) display two peaks with maximum concentrations between 0.1 and $0.7 \mu \mathrm{g} \mathrm{L}^{-1}$ (Fig. 4). First detection at SP-4 was $357 \mathrm{~h}$ after injection, and the first tracer maximum occurred after $405 \mathrm{~h}$ with $0.14 \mu \mathrm{g} \mathrm{L}^{-1}$. Mean spring discharge was $0.97 \mathrm{~m}^{3} \mathrm{~s}^{-1}$, and only $5 \%$ of this tracer was recovered. The results indicate that sorption processes in the vadose zone and remobilization after a rain event caused the second peak. The rainfall event caused spring discharge to increase to $1.25 \mathrm{~m}^{3} \mathrm{~s}^{-1}$ after peak 1, resulting in additional dilution of tracer. Mean flow velocity for the first peak is $45 \mathrm{~m} \mathrm{~h}^{-1}$. The existence 


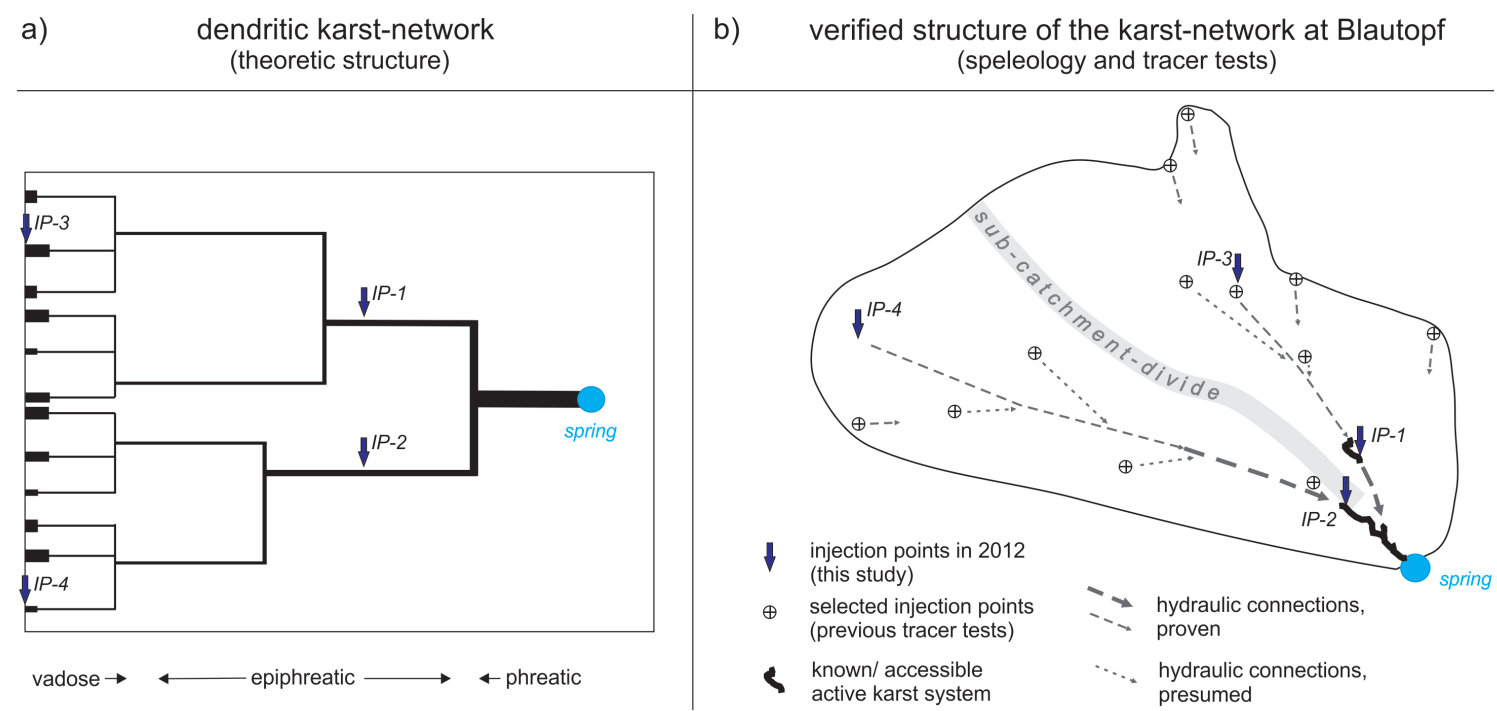

Fig. 5. (a) Theoretic structure of a hierarchical karst network with a schematic sketch of injection points. (b) Verified structure of the Blautopf spring catchment area that consists of two subcatchments, one draining towards the northern cave and the other towards the southern cave (modified from Lauber et al., 2013). The caves converge about $700 \mathrm{~m}$ linear distance upstream of the spring.

of two separate flow paths can be largely ruled out because a previous tracer test at the same injection site in 1986 exhibited a BTC with a single peak. Spring discharge at this time had been about $3.20 \mathrm{~m}^{3} \mathrm{~s}^{-1}$ with recovery of about $90 \%$ (Villinger and Ufrecht, 1989). Therefore, only the first peak of the BTC of the current test injection is modeled with CXTFIT, resulting in lower values of $R^{2}(>0.8)$.

\subsection{Structure of the drainage network}

Uranine BTCs from injections IP-1 and IP-3 monitored at SP-3 demonstrate that there is a connection between the two caves (Figs. 2, 3 and 4). Uranine was also detected at the spring (SP-4), but not in upstream parts of the southern cave (SP-2). The high similarity and the single-peaked shapes of the BTCs observed at SP-3 and SP-4 suggest that there is only one major flow path connecting the two caves. Based on tracer detection by means of the charcoal bags placed around SP-3, it was possible to precisely identify the location of the connecting conduit; this is valuable information for the further exploration of the cave (Fig. 5b).

There appear to be two main branches of drainage towards the spring - the two known caves (Figs. 2 and 5). This is confirmed by discharge measurements conducted in both cave systems. In the northern cave, a channel flow of $0.77 \mathrm{~m}^{3} \mathrm{~s}^{-1}$ was determined, while a flow of about $0.69 \mathrm{~m}^{3} \mathrm{~s}^{-1}$ was measured at SP-2 in the southern cave. At that time, discharge at the spring was $1.30 \mathrm{~m}^{3} \mathrm{~s}^{-1}$, meaning that each cave stream contributes approximately $50 \%$ of the total flow to the spring (Lauber et al., 2013).

Based on continuous tracer monitoring in the caves, it was possible to subdivide the catchment area of the Blautopf karst spring into two subcatchments contributing to the two ac- tive water caves (Fig. 5b). The northeastern part of the area drains via the northern cave into the spring, while the southwestern subcatchment is connected to the southern cave (IP2). At a distance of $700 \mathrm{~m}$ upgradient of the spring, the two cave streams merge just ahead of SP-3 and form a single, large phreatic cave passage towards the main outlet. It has been demonstrated by numerical modeling that solutionally enlarged pathways will form such dendritic drainage structures in karst aquifers, as increasing flow and dissolution are self-enhancing processes (Gabrovsek et al., 2004; Worthington and Ford, 2009; Dreybrodt et al., 2010). Although numerous flow paths exist in the epikarst and vadose zone due to discrete and diffuse infiltration, only a few preferential flow paths prevail with increasing flow distance (Fig. 5a). The rapid enlargement of such initial conduits results in reorientation of flow field towards these conduits and thus the formation of tributaries in the epiphreatic and phreatic zones. Similar drainage structures have been proven by using tracer tests in the catchment area of Milandre Cave (Perrin et al., 2007) and the Mammoth Cave system (Meiman et al., 2001).

\subsection{Flow velocities and flow parameters in the karst system}

Although conventional tracer tests with injections at the surface and monitoring at the spring represent mixed information from the entire flow path, the tracer tests presented in this study made it possible to differentiate flow in vadose, epiphreatic and phreatic cave sections. In the two cave systems, clear relations between flow types, hydraulic gradients and flow velocities have been found. The highest (mean) flow velocities of $275 \mathrm{~m} \mathrm{~h}^{-1}$ were found in the epiphreatic passage between IP-2 and SP-2. Considering a tortuosity of 1.7, 

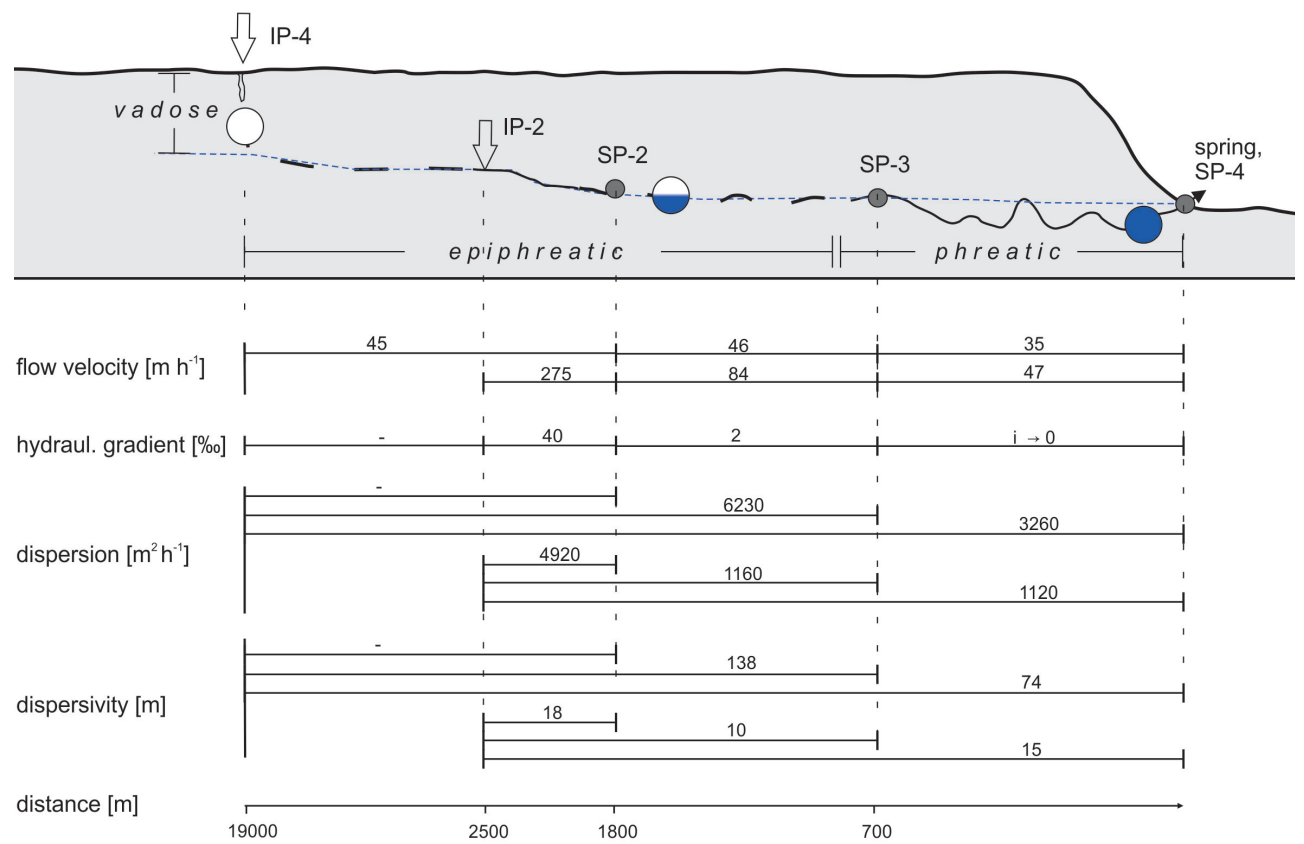

Fig. 6. Schematic sketch of injection (IP) and sampling points (SP) of the two tracer tests in the southern drainage system (Blue Cave system) and information about vadose, epiphreatic and phreatic cave passages. Below, determined flow and transport parameters are given: flow velocities and hydraulic gradients are calculated for individual cave sections, whereas dispersion and dispersivity values are valid only for sections between IPs and SPs.

maximum mean flow velocities may reach $468 \mathrm{~m} \mathrm{~h}^{-1}$. The hydraulic gradient is highest in this section at about $40 \%$ o (Fig. 6). Flow velocities decrease as they approach the main outlet due to the decreasing hydraulic gradient. Above SP3 , flow velocities decrease down to $84 \mathrm{~m} \mathrm{~h}^{-1}$ at a gradient of $2 \%$. The different hydraulic gradients can be attributed to different stages of cave development. The lowest flow velocities of 27 to $47 \mathrm{~m} \mathrm{~h}^{-1}$ were found in the phreatic cave passage between SP-3 and the spring, where the conduits are mostly below the level of the spring and thus fully saturated. Approaching the spring, the hydraulically effective cross-sectional area $(A)$ of the phreatic conduit becomes very large, resulting in a decrease of flow velocities $(v)$ according to the condition of flow continuity $(Q=v A)$. Additionally, large phreatic conduits produce a high hydraulic conductivity and therefore a very low hydraulic gradient. This leads to impoundment in the phreatic zone and the formation of underground lakes in the upgradient epiphreatic cave passages. As observed at the phreatic cave passage, flow velocities also varied with flow conditions during all four tracer tests. Discharge fluctuated between 0.97 and $1.32 \mathrm{~m}^{3} \mathrm{~s}^{-1}$, while flow velocities varied between $27 \mathrm{~m} \mathrm{~h}^{-1}$ (during lower flow conditions) and $47 \mathrm{~m} \mathrm{~h}^{-1}$ (during higher flow conditions).

Spatially, dispersion coefficients vary with flow velocities. The highest value for dispersion, $4920 \mathrm{~m}^{2} \mathrm{~h}^{-1}$, was calculated for remote parts of the cave system (Fig. 6), and can be attributed to the joint effect of rapids and pools in the cave section between IP-2 and SP-2. Similar effects have been ob- served by Hauns et al. (2001). However, close to the spring, low hydraulic gradients and low flow velocities result in a lower dispersion of about 734 to $1160 \mathrm{~m}^{2} \mathrm{~h}^{-1}$ for in-cave injections (IP-1, IP-2). A decrease in dispersion and flow velocities in proximity to a spring was also observed in a cave system in Slovenia (Gabrovsek et al., 2010).

The tracer injection at the land surface, at IP-3 (characterized by open shafts), revealed the very low water retention capacity of the vadose zone. Maximum flow velocities of $69 \mathrm{~m} \mathrm{~h}^{-1}$ were determined for the vadose and epiphreatic zone between IP-3 and SP-1, whereas only slightly higher flow velocities of 68 to $96 \mathrm{~m} \mathrm{~h}^{-1}$ were found for the downgradient cave passage between SP-1 and SP-3 (IP-1, IP-3; Table 1, Fig. 7). The BTCs of injections IP-1 and IP-3 both exhibit a symmetric peak and a short tailing; that is to say, no essential differences between cave and surface injections have been observed. However, the two injections only deliver information on the active conduit system, where flow velocities are highest. Higher water retention and lower velocities can be expected in the less karstified parts of the vadose zone. Furthermore, the seemingly minor influence of the vadose zone may be attributed to scale effects: observed values of surface injections refer to a large distance and deliver mixed information from the vadose and epiphreatic zones (Fig. 7). The thickness of the vadose zone is about $100 \mathrm{~m}$ and therefore insignificant in respect to the whole flow path of at least $10000 \mathrm{~m}$. Results from IP-3 further exhibit a low dispersion coefficient of $727 \mathrm{~m}^{2} \mathrm{~h}^{-1}$, which is similar to in-cave values 


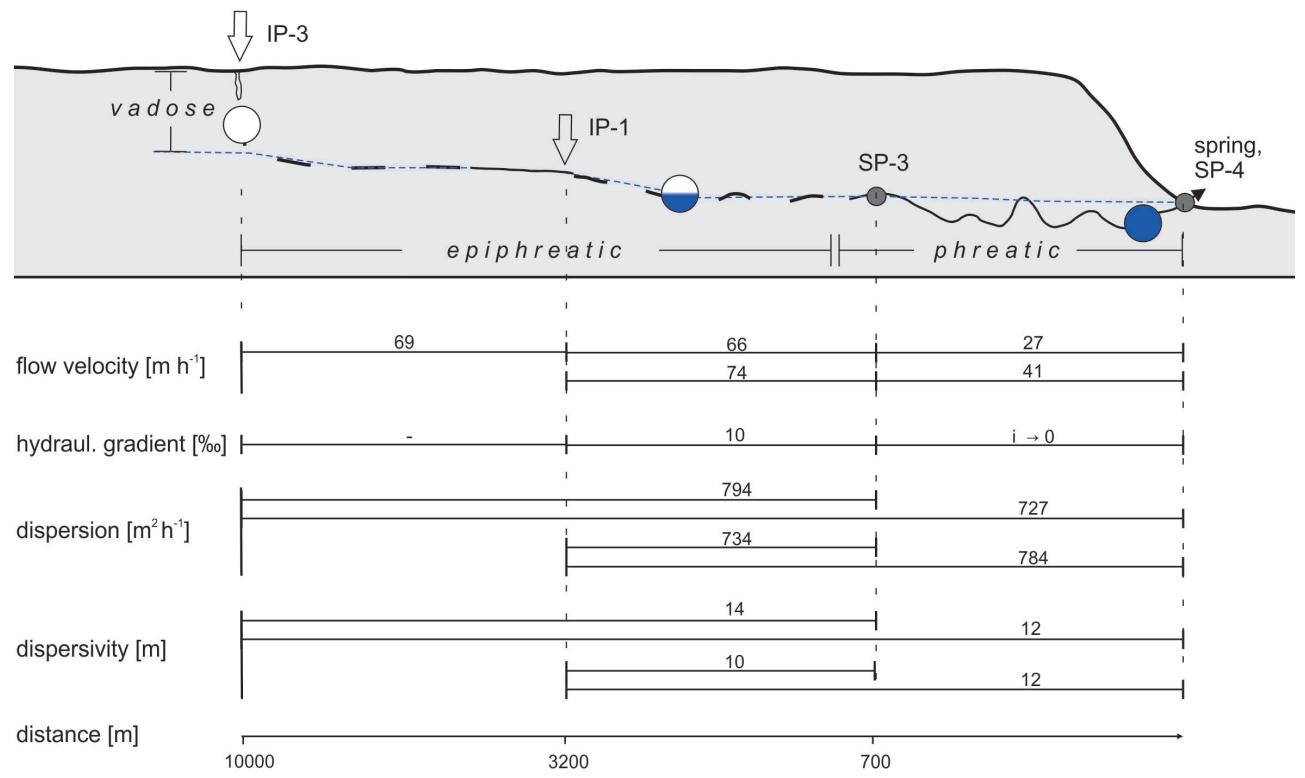

Fig. 7. Schematic sketch of the two tracer tests in the northern drainage system (Hessenhau Cave), including injection (IP) and sampling points (SP), and information about vadose, epiphreatic and phreatic cave passages. Below, determined flow and transport parameters are given: flow velocities and hydraulic gradients are calculated for individual cave sections, whereas dispersion and dispersivity values are valid only for sections between IPs and SPs.

(IP-1, Fig. 7). However, geologic profiles show that the karst water lies within the lower karst aquifer and flow paths must cross the marly formation twice in order to drain into the spring (Lauber et al., 2013). Despite this, dispersion does not increase significantly, indicating a high permeability along the flow path.

Concerning the results at IP-4, the generally lower flow velocities can be reduced to low-flow conditions during the tracer test (Fig. 6). However, maximum flow velocities are $53 \mathrm{~m} \mathrm{~h}^{-1}$, demonstrating that potential contamination would still reach the spring within a short period of time, even under low discharge from the karst system. In contrast to IP-3, dispersion coefficients from injection IP-4 produce significantly higher values of 3260 to $16700 \mathrm{~m}^{2} \mathrm{~h}^{-1}$, likely due to long flow distances and a lower permeability of the vadose zone. These results come from analysis of just the first peak and therefore may have uncertainties.

To eliminate the influence of flow velocity, the dispersivity $(\alpha=D / v)$ was calculated for all measuring points. Most values lie within the range of 10 to $18 \mathrm{~m}$ (IP-1 to IP-3). There is apparently no significant increase with flow distance within the active cave system. In contrast, the reverse was observed for IP-2: dispersivity decreases with increasing flow distance (Fig. 6). This may be due to flow in larger channels with fewer turbulences and heterogeneity. Similar effects have been observed by Gabrovsek et al. (2010) in a cave system in Slovenia. However, Hauns et al. (2001) found a strong correlation between dispersivity and flow distance in a cave system in Switzerland. An increase of dispersivity has also been observed by numerous prior surface tracer tests in the catch- ment area of Blautopf: Villinger and Ufrecht (1989) found dispersivity values from 12.4 to $38.1 \mathrm{~m}$ for distances between 3.7 and $19.0 \mathrm{~km}$, largely in agreement with the values obtained for the two cave streams during the present study.

Results with the 2RNE model of CXTFIT show a high percentage of karst water flowing in the mobile fluid region (89 to $97 \%$ ). This was calculated for cave and surface injections (IP-1 to IP-3), showing highly karstified and permeable flow paths. The mean value of mass transfer coefficient from in-cave injections is 0.62 , demonstrating low mass transfer between the immobile and mobile regions in the epiphreatic and phreatic zones. The higher mean value from surface injections (about 1.2) indicates a higher mass transfer, most likely in the vadose zone.

Large portions of the catchment are dominated by diffuse infiltration. By using water balances, spring hydrograph analyses and natural tracers, previous studies have estimated that the water volume in the fractured rock matrix accounts for 90 to $95 \%$ of the total karst water volume, which was estimated at $27 \mathrm{Mm}^{3}$. The mean residence time was calculated to be $<15$ yr (Geyer et al., 2011; Bauer and Selg, 2006; Schwarz et al., 2009; Selg and Schwarz, 2009). During the tracer tests of this study, water volumes of 0.68 and $1.42 \mathrm{Mm}^{3}$ were calculated for the conduits system of each subcatchment area (IP3 and IP-4, respectively) including the water in the phreatic conduit between the confluence of the subcatchment streams and the spring (Fig. 8). The water volume in the phreatic conduit upstream of the spring is about $0.08 \mathrm{Mm}^{3}$ and may be taken into consideration only once when calculating the total water in conduits. Thus, the total water volume in conduits 


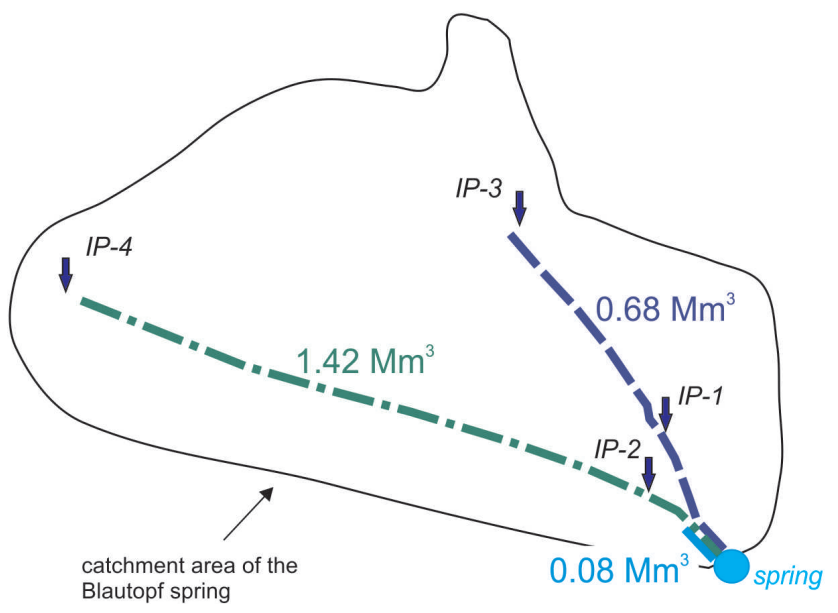

Fig. 8. Conduit water volumes estimated for each drainage system and the phreatic cave passage on the basis of the tracer test results. The total conduit volume is about $2.0 \mathrm{Mm}^{3}$.

is about $2.0 \mathrm{Mm}^{3}$ during low-flow conditions $\left(1 \mathrm{~m}^{3} \mathrm{~s}^{-1}\right)$, and corresponds to a fraction of about $7 \%$ of the total karst water of $27 \mathrm{Mm}^{3}$. In conclusion, water balances, spring hydrograph analyses and tracer tests deliver comparable estimates for conduit water volumes.

\section{Conclusions}

The results of the in-cave dye tracing and monitoring provide detailed knowledge of internal drainage structures and hydraulic properties. It was possible to demonstrate that there is only one hydraulically relevant connection between the two caves, with the confluence located about $700 \mathrm{~m}$ (linear distance) upstream of the spring. By combining land surface injections with in-cave monitoring, the dendritic drainage structure of the karst system was able to be characterized for the first time. Within the whole catchment area of the spring, two subcatchment areas were identified, each drained by an active karst conduit contributing about $50 \%$ of the discharge from the spring. At a linear distance of approximately $700 \mathrm{~m}$ upgradient of the spring, the two conduits converge and form one large phreatic cave passage. In the majority of cases, such unique insights into the drainage structure of karst aquifers are only enabled by in-cave tracer tests. The delineation of subcatchment areas can deliver valuable information regarding prediction of the spread of contaminant plumes in case of accidental release.

For the first time, detailed information on flow velocities and transport parameters were achieved for individual cave passages. Flow velocities vary strongly within the cave systems; highest flow velocities are produced by high hydraulic gradient and are found in epiphreatic cave passages. Significantly lower flow velocities were determined for the phreatic cave passage with a very low hydraulic gradient and large conduit cross section. This leads to impoundment of water in these parts of the cave system. Due to the heterogeneous distribution of flow velocities, dispersion varies in the cave systems. The highest dispersion was found for epiphreatic conduits with high flow velocity in remote parts of the cave system, whereas low dispersion generally exists in conduits with low flow velocities close to the spring. Dispersivity displays relatively constant values and does not significantly increase with increasing flow path, reflecting strong karstification. In proximity to the spring, large conduits with less turbulence and heterogeneity influence the flow parameters. Although tracer tests in active karst systems are laborious, the benefits are worth the effort since unique information on groundwater flow and flow parameters is obtained.

The volume of the conduit system was estimated and correlated with values from water balances and spring hydrograph analysis. During low-flow conditions, the fraction of conduit water is about $7 \%$ of the total karst water.

Local rural and agricultural land use affects water quality of the Blautopf. However, tracer tests available to the public have already helped to sharpen awareness of the vulnerability of water resources in the region. The obtained parameters and spatially resolved information allows for a better understanding of the structure of the karst system and may help to protect and preserve karst water resources.

Acknowledgements. We thank all cavers of the caving associations Arge Blautopf and Arge Blaukarst for their excellent cooperation, provision of cave maps and support during the tracer tests, especially Andreas Kücha and Jürgen Bohnert. Financial support was given by the Stuttgarter Hofbräu Environmental Foundation. We acknowledge support by the Deutsche Forschungsgemeinschaft and Open Access Publishing Fund of the Karlsruhe Institute of Technology. We thank Malcolm Field and an anonymous reviewer for valuable review comments and Tim Bechtel for proof-reading the manuscript.

The service charges for this open access publication have been covered by a Research Centre of the Helmholtz Association.

Edited by: Y. Fan

\section{References}

Arbeitsgemeinschaft Blautopf: Faszination Blautopf - Vorstoß in unbekannte Höhlenwelten, Jan Thorbecke, Ostfildern, 2011 (in German).

Armbuster, V. and Selg, M.: Der Abfluss des Blautopfs im Spiegel der Grundwasserneubildung (Oberjura-Karst, Süddeutschland), Tübinger Geowissenschaftliche Arbeiten, C 98, 1-16, 2006 (in German).

Bartenbach, M. and Ufrecht, W.: Stratigraphie und Fazies des Oberjuras im Umfeld der Blaubeurer Talschlinge - Ergebnisse einer Bohrung und Untertagekartierung im Blauhöhlensystem, Laichinger Höhlenfreund, 44, 89-106, 2009 (in German). 
Bartenbach, M., Möbius, R., and Aigner, T.: Neue Daten zur Geologie (Schichtenfolge, Fazies) des Oberjuras im Einzugsgebiet des Blautopfs, Laichinger Höhlenfreund, 44, 73-88, 2009 (in German).

Bauer, M. and Selg, M.: Altersstruktur und mittlere Verweilzeit im Grundwasser des Blautopfs und anderer Quellen und Brunnen im Oberjura-Karst Süddeutschlands, Tübinger Geowissenschaftliche Arbeiten (TGA), C 98, 17-44, 2006 (in German).

Bohnert, J.: Zum Stand der speläologischen Erforschung von Hessenhauhöhle (7524/117) und Seligengrundhöhle (7524/119) durch die Arbeitsgemeinschaft Blaukarst, Laichinger Höhlenfreund, 44, 37-44, 2009 (in German).

Dreybrodt, W., Romanov, D., and Kaufmann, G.: Evolution of caves in porous limestone by mixing corrosion: A model approach, Geol. Croat., 63, 129-135, doi:10.4154/gc.2010.09, 2010.

Field, M. S. and Nash, S. G.: Risk assessment methodology for karst aquifers: 1. Estimating karst conduit-flow parameters, Environ. Monit. Assess., 47, 1-21, doi:10.1023/A:1005753919403, 1997.

Field, M. S. and Pinsky, P. F.: A two-region nonequilibrium model for solute transport in solution conduits in karstic aquifers, J. Contam. Hydrol., 44, 329-351, doi:10.1016/S01697722(00)00099-1, 2000.

Gabrovsek, F., Romanov, D., and Dreybrodt, W.: Early karstification in a dual-fracture aquifer: the role of exchange flow between prominent fractures and a dense net of fissures, J. Hydrol., 299, 45-66, doi:10.1016/j.jhydrol.2004.02.005, 2004.

Gabrovsek, F., Kogovsek, J., Kovacic, G., Petric, M., Ravbar, N., and Turk, J.: Recent results of tracer tests in the catchment of the Unica River (SW Slovenia), Acta Carsologica, 39, 27-37, 2010.

Geyer, T., Birk, S., Licha, T., Liedl, R., and Sauter, M.: Multitracer Test Approach to Characterize Reactive Transport in Karst Aquifers, Ground Water, 45, 36-45, doi:10.1111/j.17456584.2006.00261.x, 2007.

Geyer, T., Selg, M., Gudera, T., and Sauter, M.: Langzeitabflussverhalten der Gallusquelle und des Blautopfs - relative Bedeutung der Matrix und des Großkluftsystems, Laichinger Höhlenfreund, 46, 63-74, 2011 (in German).

Goldscheider, N. and Drew, D.: Methods in Karst Hydrogeology, Taylor \& Francis, London, 2007

Goldscheider, N., Meiman, J., Pronk, M., and Smart, C.: Tracer tests in karst hydrogeology and speleology, Int. J. Speleol., 37, 27-40, doi:10.5038/1827-806X.37.1.3, 2008.

Göppert, N. and Goldscheider, N.: Solute and Colloid Transport in Karst Conduits under Low- and High-Flow Conditions, Ground Water, 46, 61-68, doi:10.1111/j.1745-6584.2007.00373.x, 2008.

Hauns, M., Jeannin, P.-Y., and Atteia, O.: Dispersion, retardation and scale effect in tracer breakthrough curves in karst conduits, J. Hydrol., 241, 177-193, doi:10.1016/S0022-1694(00)00366-8, 2001.

Lauber, U., Ufrecht, W., and Goldscheider, N.: Neue Erkenntnisse zur Struktur der Karstentwässerung im aktiven Höhlensystem des Blautopfs, Grundwasser, 18, 247-257, doi:10.1007/s00767013-0239-z, 2013 (in German).

Massei, N., Wang, H. Q., Field, M. S., Dupont, J. P., Bakalowicz, M., and Rodet, J.: Interpreting tracer breakthrough tailing in a conduit-dominated karstic aquifer, Hydrogeol. J., 14, 849-858, doi:10.1007/s10040-005-0010-3, 2006.
Meiman, J., Groves, C., and Herstein, S.: In-cave dye tracing and drainage basin divides in the Mammoth Cave karst aquifer, Kentucky, US Geological Survey Water Resources Investigations Report, 01-4011, 179-185, 2001.

Morales, T., Valderrama, I., Uriarte, J., Antigüedad, I., and Olazar, M.: Predicting travel times and transport characterization in karst conduits by analyzing tracer-breakthrough curves, J. Hydrol., 334, 183-198, doi:10.1016/j.jhydrol.2006.10.006, 2007.

Mudarra, M. and Andreo, B.: Relative importance of the saturated and the unsaturated zones in the hydrogeological functioning of karst aquifers: The case of Alta Cadena (Southern Spain), J. Hydrol., 397, 263-280, doi:10.1016/j.jhydrol.2010.12.005, 2011.

Palmer, A. N.: Origin and morphology of limestone caves, Geol. Soc. Am. Bull., 103, 1-21, doi:10.1130/00167606(1991)103<0001:OAMOLC>2.3.CO;2, 1991.

Perrin, J., Jeannin, P.-Y., and Cornaton, F.: The role of tributary mixing in chemical variations at a karst spring, Milandre, Switzerland, J. Hydrol., 322, 158-173, doi:10.1016/j.jhydrol.2006.06.027, 2007.

Pronk, M., Goldscheider, N., Zopfi, J., and Zwahlen, F.: Percolation and particle transport in the unsaturated zone of a karst aquifer, Ground Water, 47, 361-369, doi:10.1111/j.17456584.2008.00509.x, 2009.

Ravbar, N., Engelhardt, I., and Goldscheider, N.: Anomalous behaviour of specific electrical conductivity at a karst spring induced by variable catchment boundaries: the case of the Podstenjšek spring, Slovenia, Hydrol. Process., 13, 2130-2140, doi:10.1002/hyp.7966, 2011.

Schwarz, K., Barth, J. A. C., Postigo-Rebollo, C., and Grathwohl, P.: Mixing and transport of water in a karst catchment: a case study from precipitation via seepage to spring, Hydrol. Earth Syst. Sci., 13, 285-292, doi:10.5194/hess-13-285-2009, 2009.

Selg, M. and Schwarz, K.: Am Puls der schönen Lau - zur Hydrogeologie des Blautopf-Einzugsgebietes, Laichinger Höhlenfreund, 44, 45-72, 2009 (in German).

Smart, C. C.: Artificial tracer techniques for the determination of the structure of conduit aquifers, Ground Water, 26, 445-453, doi:10.1111/j.1745-6584.1988.tb00411.x, 1988.

Toride, N., Leij, F. J., and van Genuchten, M. T.: The CXTFIT code for estimating transport parameters from laboratory or field tracer experiments, Riverside, California: US Salinity Laboratory USDA, ARS. Research Report No. 137, 1999.

Ufrecht, W.: Schichtlagerung und Bruchtektonik im Einzugsgebiet des Blautopfs und dessen Umfeld (Mittlere Schwäbische Alb), Laichinger Höhlenfreund, 44, 107-148, 2009 (in German).

Van Genuchten, M. Th., Šimůnek, J., Leij, F. J., Toride, N., and Šejna, M.: STANMOD: Model use, calibration and validation, Trans. ASABE, 55, 1353-1366, 2012.

Villinger, E. and Ufrecht, W.: Ergebnisse neuer Markierungsversuche im Einzugsgebiet des Blautopfs (mittlere Schwäbische Alb), Mitt. Verb. dt. Höhlen- u. Karstforscher, 35, 25-38, 1989 (in German).

Winston, W. E. and Criss, R. E.: Dynamic hydrologic and geochemical response in a perennial karst spring, Water Resour. Res., 40, W05106, doi:10.1029/2004WR003054, 2004.

Worthington, S. and Ford, D. C.: Self-Organized Permeability in Carbonate Aquifers, Ground Water, 47, 326-336, doi:10.1111/j.1745-6584.2009.00551.x, 2009. 